\title{
Diet and microhabitat use by juveniles Rhinella ornata (Anura, Bufonidae) in an insular Brazilian Atlantic Rainforest area
}

\author{
C. N. Flynn ${ }^{a *}$ (D) P. G. Araújo ${ }^{b}$ (D) and C. F. D. Rocha ${ }^{a}$ (D) \\ aUniversidade do Estado do Rio de Janeiro - UERJ, Departamento de Ecologia, Laboratório de Ecologia de Vertebrados, \\ Rio de Janeiro, RJ, Brasil \\ 'Instituto Moleque Mateiro de Educação Ambiental, Rio de Janeiro, RJ, Brasil \\ *e-mail: cnflynn97@gmail.com
}

Received: April 14, 2020 - Accepted: June 8, 2020

Anuran diet studies in Tropical Forests such as the Brazilian Atlantic Rainforest (BAF) are common for adults, but few analyses include juveniles probably because they are less frequent along the year in comparison to adults (Duellman and Trueb, 1994). Diet composition can vary depending on seasonal prey abundance (e.g. Santana and Juncá, 2007) and differences in body size during ontogeny (e.g. Flowers and Graves, 1995). Rhinella ornata (Spix, 1824) occurs in BAF, from south of Espírito Santo to north of Paraná state, and possibly in Argentina and Paraguay (Frost, 2017). Available ecological information on $R$. ornata is restricted to its reproductive modes (e.g. Pombal Junior and Haddad, 2007), development and body size (Rebouças et al., 2019), ecosystems energy flow (Ohashi and Silva, 2009), activity (Rocha et al., 2011) and adults feeding habits, microhabitat use and daily activity period (e.g. Maia-Carneiro et al., 2013). However, there are no studies focusing on juvenile's main microhabitat and feeding ecology. Herein, we analyzed the microhabitat use and diet of Rhinella ornata juveniles in an insular BAF habitat. The study was carried out from January to March 2004 in the trail that connects Vila Dois Rios to Caxadaço beach (23 $\left.11^{\prime} \mathrm{S}, 44^{\circ} 12^{\prime} \mathrm{W}\right)$, located in Ilha Grande, a continental island in Rio de Janeiro state, Brazil. Individuals were collected through Visual Encounter Surveys performed by crepuscular and nocturnal transects along the trail. All individuals in our sample were below $60.0 \mathrm{~mm}$ (SVL), which represents the maturity size for $R$. ornata (Rebouças et al., 2019). Diet composition was analyzed in terms of number $(\mathrm{N})$, volume (V), and frequency (F) of occurrence of each prey type. Each prey was identified to the lowest possible taxonomic level and had its length (L) and width (W) measured with a caliper to the nearest $0.01 \mathrm{~mm}$. We used the formula for an ovoid spheroid to estimate prey volume: $[\mathrm{V}=4 / 3 . \pi$. (L / 2) $(\mathrm{W} / 2)^{2}$ ] (Dunham, 1983). An index of relative importance (IRI) was also calculated for each prey category, using the following formula: $[$ IRI $=(\% \mathrm{~N}+\% \mathrm{~V})$ $\%$ F] (Pinkas et al., 1971). To characterize the species microhabitat, we registered all potential microhabitats in each sample site to obtain their frequency distributions and recorded their types where individuals were first found during transects. We analyzed the stomach content from a total of 52 individuals of Rhinella ornata from which five stomachs were empty (10.4\%). In terms of number, juveniles of $R$. ornata fed predominantly on Hymenoptera (Formicidae) (72.9\%) and Isopoda (11.4\%) (Table 1). Ants (Formicidae) also represented most of the prey volume (about 44\%) and frequency (around 90\%). A diet composed mainly by Formicidae is consistent with previous diet studies with adults of this and other congeneric species, which were followed by Coleoptera and Isoptera (Ferreira and Teixeira, 2009; Sabagh et al., 2012; Maia-Carneiro et al., 2013). However, in our study, Coleoptera and Isoptera were items with relatively low IRI (20.4 and 15.86, respectively). Instead, Acari and Isopoda had higher values (IRI 202.12 and 236.35, respectively). Yet, both Acari and Isopoda did not even appear as prey for adults of $R$. ornata in the study of Maia-Carneiro et al. (2013). This consumption of such small prey might be explained by the expected lower range of prey size available in the environment for smaller-sized frogs. Our results are in line with a research with the congeneric $R$. icterica in the south BAF, which found ants and mites as important prey items for toadlets, in contrast to adults who fed mainly on ants, Coleoptera and other Hymenoptera (Solé et al., 2017). Some studies have analyzed the relation between body size and diet shift in bufonids species (e.g. Gittins 1987; Quiroga et al., 2009). This ontogenetic change was recorded to occur in the bufonid toad Anaxyrus woodhousii from United States and Mexico and was suggested as a specialization of juveniles on beetles (Flowers and Graves, 1995). According to Maia-Carneiro et al. (2013), R. ornata has generalist and opportunistic foraging habits. Although the largest portion of $R$. ornata juveniles' diet was composed by Formicidae, our work did not measure prey availability, which precludes us from assuming prey specialization. We found a total of seven potential microhabitats that were used by individuals of $R$. ornata but in different frequencies: Leaf-litter (18\%), Tree root (17\%), Tree trunk (16\%), Trunk (16\%), Leaf (16\%), Rock (12\%) and on Bromeliads (5\%). All juveniles of $R$. ornata were found on the leaf-litter. This result can be somewhat biased since it is easier to detect small toads on the forest floor than on more hidden microhabitats. However, it does concur with what was found for $R$. ornata adults, that occupy a variety of microhabitats, but mostly the leaf-litter and bare ground (Maia-Carneiro et al., 2013). We concluded that 
Table 1. Diet composition of Rhinella ornata juveniles $(\mathrm{N}=52)$ from an Atlantic rainforest area in Ilha Grande, Rio de Janeiro state, Brazil.

\begin{tabular}{|c|c|c|c|c|}
\hline Prey & $\mathbf{N}(\%)$ & V (\%) & F (\%) & IRI \\
\hline \multicolumn{5}{|l|}{ Insecta } \\
\hline Larvae & $7(1.9)$ & $4.10(0.4)$ & $7(14.2)$ & 32.66 \\
\hline Coleoptera & $4(1.1)$ & $8.97(0.9)$ & $5(10.2)$ & 20.4 \\
\hline Isoptera & $9(2.4)$ & $2.19(0.2)$ & $3(6.1)$ & 15.86 \\
\hline Hymenoptera (Non ants) & $6(1.6)$ & $2.19(0.2)$ & $4(8.1)$ & 14.58 \\
\hline Hymenoptera (Formicidae) & $267(72.9)$ & $440.10(43.8)$ & $44(89.7)$ & $10,467.99$ \\
\hline \multicolumn{5}{|l|}{ Arachnida } \\
\hline Acari & $20(5.5)$ & $6.80(0.7)$ & $16(32.6)$ & 202.12 \\
\hline Araneae & $11(3.0)$ & $6.94(0.7)$ & $6(12.2)$ & 45.14 \\
\hline \multicolumn{5}{|l|}{ Crustacea } \\
\hline Isopoda & $42(11.4)$ & $31.70(3.1)$ & $8(16.3)$ & 236.35 \\
\hline Arthropods remains & - & $430.02(42.8)$ & $30(61.2)$ & $2,619.36$ \\
\hline Plant remains & - & $68.61(6.8)$ & $6(12.2)$ & 82.96 \\
\hline Total & $366(100)$ & $1003.3(100)$ & & \\
\hline
\end{tabular}

The table shows the number $(\mathrm{N})$, volume $\left(\mathrm{V}\right.$, in $\left.\mathrm{mm}^{3}\right)$, frequency of occurrence $(\mathrm{F})$ and the index of relative importance (IRI) of each food item (percentages in parentheses).

the juveniles of $R$. ornata in Ilha Grande diet composition may differ from adults by including smaller preys, and that their main microhabitat is the leaf-litter on the ground level, which leads to exclusively horizontal habitat use. Future studies on prey fluctuation and with samples from different seasons are needed for a further understanding on this species ontogenetic diet shift.

\section{Acknowledgements}

We thank the Instituto Estadual do Ambiente (Inea) for the permit of the Project at Ilha Grande and the Centro de Estudos Ambientais e Desenvolvimento Sustentável - CEADS of UERJ for logistic support. CNF received funds from CAPES. CFDR received funds from Conselho Nacional do Desenvolvimento Científico e Tecnológico - CNPq (Processes No. 302974/2015-6 and 424473/20160 ), and from Fundação Carlos Chagas Filho de Amparo à Pesquisa do Estado do Rio de Janeiro - FAPERJ, through "Cientistas do Nosso Estado" Program (E-26/202.920.2015 and E-26/202.803/2018).

\section{References}

DUELLMAN, W.E. and TRUEB, L., 1994. Biology of amphibians. Baltimore: Johns Hopkins, 670 p.

DUNHAM, A.E., 1983. Realized niche overlap, resource abundance, and intensity of interspecific competition. In: R.B. HUEY, E.R. PIANKA and T.W. SCHOENER, eds. Lizard ecology: studies of a model organism. Cambridge: Harvard University Press, pp. 261-280.

FERREIRA, R.B. and TEIXEIRA, R.L., 2009. Feeding pattern and use of reproductive habitat of the Striped toad Rhinella crucifer (Anura: Bufonidae) from Southeastern Brazil. Acta Herpetologica, vol. 4, no. 2, pp. 125-134.
FLOWERS, M.A. and GRAVES, B.M., 1995. Prey selectivity and size-specific diet changes in Bufo cognatus and B. woodhousii during early postmetamorphic ontogeny. Journal of Herpetology, vol. 29, no. 4, pp. 608-612. http://dx.doi.org/10.2307/1564745.

FROST, D.R. 2017 [viewed 4 April 2020]. Amphibian species of the world: an online reference. Version 6.1 [online]. Available from: http://research.amnh.org/herpetology/amphibia/index.html

GITTINS, S.P., 1987. The diet of the common toad (Bufo bufo) around a pond in mid-wales. Amphibia-Reptilia, vol. 8, no. 1, pp. 13-17. http://dx.doi.org/10.1163/156853887X00027.

MAIA-CARNEIRO, T., KIEFER, M.C., VAN SLUYS, M. and ROCHA, C.F.D., 2013. Feeding habits, microhabitat use, and daily activity period of Rhinella ornata (Anura, Bufonidae) from three Atlantic rainforest remnants in southeastern Brazil. North-Western Journal of Zoology, vol. 9, no. 1, pp. 157-165.

OHASHI, T.L. and SILVA, V.X., 2009. Importância da biomassa de Rhinella ornata (Anura, Bufonidae) para o fluxo de energia água-terra no Parque Estadual Nova Baden, Lambari - MG. In: Anais do $3^{\circ}$ Congresso Latino Americano de Ecologia, 10-13 September, São Lourenço, MG, Brasil. São Paulo: USP, pp. 1-3.

PINKAS, L., OLIPHANT, M.S. and IVERSON, Z.L., 1971. Food habits of albacore bluefin, tuna and bonito in California waters. State of California The Resources Agency Department of Fish and Game Fish Bulletin, vol. 152, pp. 1-350.

POMBAL JUNIOR, J.P. and HADDAD, C.F.B. 2007. Estratégias e modos reprodutivos de anuros. In: L.B. NASCIMENTO and P.M.E. OLIVEIRA, eds. Herpetologia no Brasil II. São Paulo: Sociedade Brasileira de Herpetologia, pp. 101-116.

QUIROGA, L.B., SANABRIA, E.A. and ACOSTA, J.C., 2009. Size-and sex- dependent variation in diet of Rhinella arenarum (Anura: Bufonidae) in a Wetland of San Juan, Argentina. Journal of Herpetology, vol. 43, no. 2, pp. 311-317. http://dx.doi. org/10.1670/07-117R2.1.

REBOUÇAS, R., SILVA, H.R., SANUY, D. and SOLÉ, M., 2019. Sexual maturity and growth of male toads (Rhinella ornata): A comparison between insular and mainland populations. Zoologischer Anzeiger, vol. 283, pp. 12-19. http://dx.doi.org/10.1016/j.jcz.2019.07.002. 
ROCHA, C.F.D., VRCIBRADIC, D., KIEFER, M.C., SIQUEIRA, C.C., ALMEIDA-GOMES, M., BORGES JÚNIOR, V.N., HATANO, F.H., FONTES, A.F., PONTES, J.A., KLAION, T., GIL, L.O. and SLUYS, M.V., 2011. Parameters from the community of leaf-litter frogs from Estação Ecológica Estadual Paraíso, Guapimirim, Rio de Janeiro State, southeastern Brazil. Anais da Academia Brasileira de Ciências, vol. 83, no. 4, pp. 1259-1267. http://dx.doi.org/10.1590/S0001-37652011005000036. PMid:21971595.

SABAGH, L.T., CARVALHO-E-SILVA, A.M.P.T. and ROCHA, C.F.D., 2012. Diet of the toad Rhinella icterica (Anura: Bufonidae) from Atlantic Forest Highlands of southeastern Brazil. Biota
Neotropica, vol. 12, no. 4, pp. 258-262. http://dx.doi.org/10.1590/ S1676-06032012000400027.

SANTANA, A.S. and JUNCÁ, F.A., 2007. Diet of Physalaemus cf. cicada (Leptodactylidae) and Bufo granulosus (Bufonidae) in a semideciduous forest. Brazilian Journal of Biology $=$ Revista Brasileira de Biologia, vol. 67, no. 1, pp. 125-131. http://dx.doi. org/10.1590/S1519-69842007000100017. PMid:17505759.

SOLÉ, M., ROCHA, M.S., DECARLI, C., SANTOS, C.R. and PEREIRA, C.K., 2017. Diet of post-metamorphic Rhinella icterica (Spix, 1824) from the Araucaria Plateau of Rio Grande do Sul, Brazil (Anura: bufonidae). Herpetology Notes, vol. 10, pp. 443-448. 